\title{
A gyógytestnevelés jelentősége a szekunder rehabilitáció és egészségfejlesztés folyamatában - A megújulás szükségessége és irányai
}

\author{
Significance, reorientation, need for renewal of adapted physical education \\ in the secondary rehabilitation and health development process
}

\author{
Szerzők: Simon István Ágoston $\bowtie$, Kajtár Gabriella \\ Soproni Egyetem Benedek Elek Pedagógiai Kar, Müvészeti és Sporttudományi Intézet
}

Beküldve: 2017. 12. 15.

doi: $10.24365 /$ ef.v59i1.222

\begin{abstract}
Összefoglaló: Örvendetes, hogy Magyarországon egyre nagyobb publicitást kap az egészség megőrzésével, fejlesztésével kapcsolatos tevékenységek jelentőségének hangsúlyozása. Hazánkban a fiatal, a felnőtt és az idős lakosság egészségi állapotának minősége még nem éri el a kívánt szintet, ezért szükség van olyan tevékenységek propagálására, amelyek elősegítik a lakosság egészségének minél magasabb szintre emelését. Ezek közé tartozik a gyógytestnevelés is, amely Európában egyedülálló módon - a problémák ellenére is - magas szintű szervezettséggel és megfelelő hatékonysággal valósítja meg az iskolai rehabilitációt, és segíti a tanulók egészségfejlesztését. A több mint 100 éve szervezett formában megvalósuló gyógytestnevelést napjainkban számos probléma és új körülmény övezi, amelyek részben negatívan befolyásolják hatékonyságát, ugyanakkor új lehetőséget mutatnak. Szükségessé vált a gyógytestnevelés fogalmának, céljainak, feladatainak újradefiniálása, a rehabilitáció és az egészségfejlesztés folyamatában betöltött szerepének meghatározása, a fejlesztés irányainak kijelölése.
\end{abstract}

Kulcsszavak: gyógytestnevelés, szekunder rehabilitáció, megújulás

\begin{abstract}
Summary: It is encouraging that in Hungary the significance of activities in connection with health preservation and development are publicised more and more widely. The quality of health condition of the young, adult and older population has not still achieved the required level in our country for that reason there is a need for promoting activities that encourage upgrading the health of Hungary's population. These activities include adapted physical education, which, uniquely in Europe - and despite the problems - pursues school rehabilitation and health development in an adequate and effective manner and with an appropriate degree of organization. Although adapted physical education has been functioning in an organized way for more than 100 years, it has to face several problems and new circumstances, which have a negative impact on its efficiency, but on the other hand, provide new opportunities as well. The new situation makes it necessary to redefine the concept, objectives and tasks of adapted physical education as well as to define the frames of development and its role in the rehabilitation and health development process.
\end{abstract}

Keywords: adapted physical education, secondary rehabilitation, renewal

A rendszeres testedzés egészség-helyreállító, megtartó és fejlesztő hatását már az ókorban is felismerték és kihasználták. A terápiás céllal összeállított mozgásprogramok, a gyógygimnasztikák a XIX. században kezdtek terjedni szélesebb körben a világon, köztük Magyarországon. A Il. világháború előtti Magyarországon számos neves személyiség, orvos (pl. Schöpf-Mérei Ágoston, Batizfalvy Sámuel, 
Dr. Dollinger Béla) állt ki a gyógygimnasztika jelentősége és fontossága mellett. ${ }^{1,2}$ Ennek következménye lett a gyógytestnevelés elválása a gyógytornától, és iskolai bevezetése 1915-ben, majd egyre szélesebb körben való elterjesztése a későbbi években. A robbanásszerű fejlődés az 1950-es évektől számolható, aminek következtében számos szakirodalom jelent meg a Testnevelési Főiskola tanárai jóvoltából, akiknek köszönhetjük a magyarországi gyógytestnevelés magas színvonalú megjelenését. Dr. Csider Tibor, Dr. Nemessúri Mihály, Gárdos Magda, Dr. Mónus András: az ő szakmai útmutatójukból, tankönyveiból dolgozik nagyrészt még ma is a gyógytestnevelés szakma. Kijelenthetjük, hogy a gyógytestnevelés érték, amely Európában már csak Magyarországon van jelen ebben a szerteágazó és minden kritikai megjegyzés ellenére - hatékony formában. Az európai színtéren nem tudják definiálni a gyógytestnevelést, mert az iskolai rehabilitáció ilyen mérvü

szerevezettsége nem ismert az európai országokban. Szinte azt mondhatjuk, a gyógytestnevelés „hungarikum”. Mindezen pozitívumok ellenére a gyógytestnevelés jelenleg számos problémával küzd. Nem a gyógytestnevelő tanárok elhivatottsága, szakmai igényessége és a gyermekek iránti odaadása csökkent, hanem a gyógytestnevelést körülvevő közeg, a törvényi szabályozás megváltoztatása és az egészség helyreállításáért, fejlesztéséért, megőrzéséért tevő szakmák közti koordináció hiánya okozza a felmerülő problémákat. A gyógytestnevelésnek szükségszerűen meg kell újulnia, szerkezetileg, szakmailag. A fentiek érdekében újra kell definiálni a gyógytestnevelés fogalmát, céljait, feladatait, hogy egyértelműen, megalapozottan meg tudjuk határozni területeit, szerepét a rehabilitáció és egészségfejlesztés folyamatában, helyét a nevelés-oktatás rendszerében. A fiatal és felnőtt lakosság egészségi állapotának javítása Magyarországon fontos feladat, amelyben a gyógytestnevelésnek, mint speciális nevelési területnek meghatározó szerepet kell betöltenie. A szakemberek szakmai, pedagógiai felkészültsége, szemlélete, elhivatottsága az egészség-helyreállitás és -fejlesztés területén indokolttá teszi, hogy a gyógytestnevelés ne csak az iskolás korosztály számára váljék elérhe- tővé, hanem a felnőtt, az idős lakosság és a sportolók számára is.

Tanulmányunkban a gyógytestnevelés helyzetének rövid elemzése után fogalmának, céljainak, feladatainak, rehabilitációban betöltött szerepének újradefiniálásán keresztül szeretnénk meghatározni a gyógytestnevelés helyét, szerepét és jövőképét az iskolás korosztály, illetve a felnőtt, idős lakosság és a sportolók egészség helyreállítása és fejlesztése területén. Az előzőekben leírtak elengedhetetlen feltételei a megújulásnak, az elfogadottságnak, és útmutatóul szolgálhatnak a döntéshozóknak és a gyógytestnevelő tanár társadalomnak az elkövetkező időszak munkájához.

\section{A GYÓGYTESTNEVELÉS HELYZETE NAPJAINKBAN}

Az 1993. évi LXXIX. törvény a közoktatásról lehetőséget adott a gyógytestnevelés több megjelenési formájára. A gyógytestnevelést lehetett szervezni iskolában, szakszolgálati rendszerben és kistérségi társulás keretében. A különböző megjelenési formák révén az ellátandó tanulók egy kijelölt központi helyen vagy saját iskolájukban vehettek részt a gyógytestnevelés órán. Minden esetben a helyi adottságoknak megfelelően a legjobb megjelenési forma valósulhatott meg. A gyógytestnevelő tanárok a tanulókkal közvetlen viszonyt, jó munkakapcsolatot tudtak kialakítani a napi rendszerességgel létrejövő találkozások révén. A rendszerben voltak hibák, de alapvetően jól múködött. Ezt az állapotot változtatta meg negatív irányba a Nemzeti Köznevelésről szóló 2011. évi CXC. törvény és a 15/2013. (II. 26.) EMMI rendelet a pedagógiai szakszolgálati intézmények múködéséről, amikor a pedagógiai szakszolgálatok körébe sorolta a gyógytestnevelést, és így az kikerült a közismereti tantárgyak közül. A törvényi változások következtében a gyógytestnevelő tanárok kikerültek az iskola kötelékéből, és az eddig meglevő jó tanár-tanuló kapcsolatrendszer negatívan megváltozott. A szakszolgálati rendszerben tevékenykedo" „utazó” gyógytestnevelő tanárok sok esetben - mivel nincsenek naponta jelen az intézményben - nem tudnak kialakítani megfelelő pedagógiai kapcsolatot a tanulókkal, ami alapfelté-

i Dr. Gunda András a Testnevelési Egyetem gyógytestnevelés képzésért évtizedekig felelős oktatója határozta így meg a gyógytestnevelést több alkalommal. 
tele a sikeres rehabilitációs tevékenységnek. Az előbb vázolt helyzetet súlyosbítja, hogy az egészségügy, nem ismerve a gyógytestnevelés céljait, feladatait, szemléletformálásban és a rehabilitációs folyamatban betöltött meghatározó szerepét, nem együttmúködő partnerként, hanem néhány területen (helytelenül) „versenytársként" tekint a gyógytestnevelésre. A változásoknak azonban vannak pozitív eredményei is. A szakszolgálati rendszer lehetőséget ad a gyógytestnevelő szakma összefogására, és ezáltal az új szakmai ismeretek minél gyorsabb eljuttatatására a gyógytestnevelő tanárokhoz, szakmai munkaközösségek létrehozására, az ellátás minél szélesebb körú megszervezésére, de a gyermekek személyiségformálására, egészségtudatos nevelésére teljes mértékig nem alkalmas. Összegezve elmondható, hogy az iskolai gyógytestnevelés jelenlegi helyzete nehéz, de az alapvető szakmai kritériumok - mint a gyógytestnevelő tanárok szakmai, pedagógiai felkészültsége, ${ }^{3}$ elhivatottsága, az ellátás szervezettsége, a szakmai továbbképzési rendszer - stabilan jelen vannak. Ezek alapot adnak a pozitív jövőkép kialakításához és annak megvalósításához.

\section{A GYÓGYTESTNEVELÉS JÖVŐJÉT ÉS SZEREPÉT BEFOLYÁSOLÓ ÚJ TÉNYEZŐKK}

A magyarországi felnőtt társadalom egészségi állapota az egyik legrosszabb az EU-ban, a vezető halálokok közt megtalálhatjuk a szív- és érrendszeri, daganatos betegségeket, illetve magas az életminőséget negatívan befolyásoló mozgásszervi elváltozások aránya is. Ezek a tények komoly terhet rónak az államra, azon belül az egészségügyi ellátórendszerre. Tovább nehezíti a helyzetet, hogy a felnőtt lakosság várható élettartama kitolódik, a 65 év feletti korosztály aránya 2030-ra elérheti a 21,5\%-ot is. ${ }^{4}$ A várható élettartam Magyarországon 2015-ben 78,61 év volt, ${ }^{5}$ és sajnos elmondható, hogy a 65 év fölötti korosztály a legérintettebb a krónikus betegségek szempontjából, ami nagy anyagi terhet ró a társadalomra. Szükséges olyan prevenciós, rehabilitációs tevékenységeket előtérbe helyezni, amelyek elősegítik a felnőtt lakosság egészségi állapotának pozitív irányú megváltozását.

Az oktatásirányítás döntése alapján a felsőoktatási képzésben 2013 szeptemberétől felmenő rendszerben hozzárendelték az egészségfejlesztés tanár szakot a gyógytestnevelő tanár szakhoz, ennek révén a gyógytestnevelő tanárnak lehetősége nyílik az iskolás és felnőtt lakosság egészségfejlesztési tevékenységének szervezésére, irányítására, elősegítve a lakosság egészségi állapotának pozitív változását.

A mindennapos testnevelés bevezetése, a sportakadémiák létrejötte a pozitív hatások mellett számos sportsérülést is eredményezhet. A sportrehabilitáció jelenleg az utánpótlásképzés területén nem teljesen megoldott. A primer rehabilitáció (gyógytorna) után a szekunder rehabilitációt általában nem alkalmazzák, holott a versenysportba történő minél gyorsabb visszatérés, az eredeti teljesítmény visszaállítása elvárás a versenyzők és a sportvezetés részéről is. A gyógytestnevelés ezen a területen is meghatározó szerepet tölthet be, ennek indokait a későbbiekben fejtjük ki.

\section{A GYÓGYTESTNEVELÉS FOGALMA, CÉபA, FELADATA, HELYE A REHABILITÁCIÓS FOLYAMATBAN}

A gyógytestnevelés fogalmát az eddigi meghatározások ${ }^{7,8}$ leszúkítették az iskoláskorúak gyógytestnevelésére, ${ }^{6,7,8}$ miközben az előzőekben leírt hatások következtében a gyógytestnevelés több, mint az iskoláskorúak intézményesített rehabilitációja. A gyógytestnevelés fejlődésének gátja lehet, ha csak az iskolai szekunder rehabilitációra, prevencióra szúkítjük le a tevékenységet, miközben egyre nagyobb igény merül fel más területeken e speciális testedzési forma végzésére.

A gyógytestnevelés tágabb értelemben (adaptált testedzés) olyan rendszeres testedzés és szemléletformálás, amely a sport és a nevelés eszközeit, módszereit adaptált módon felhasználva segítséget nyújt az egészségi állapot és a teljesitőképesség minél nagyobb mértékü helyreállitásában. ${ }^{2}$

A tágabb értelmezés felöleli az iskolai gyógytestnevelés mellett a felnőttek (idősek), a sportolók és a fogyatékkal élők szekunder rehabilitációs tevékenységét is.

Szükebb értelmezésben a gyógytestnevelés (adaptált testnevelés) olyan oktatási-nevelési folyamat, amely az egyéni sajátosságok maximális figyelembevételével a testnevelés és a sport azon eszközeit, módszereit használja fel, amelyek az egészségi állapot és a teljesitöképesség minél nagyobb mértékü helyreállitásához és az esélyegyenlöség megteremtéséhez nyújt segitséget. ${ }^{2}$ 
Az eddigi meghatározásokhoz képest új elem az egyéni sajátosságok figyelembevétele és a teljesítőképesség helyreálítása, amelyek az adaptált fizikai aktivitástól és a kórházi gyógytornától való egyértelmü elkülönitést szolgálják.

A gyógytestnevelés célja kettős: egyrészt a testnevelés céljait figyelembe véve a megváltozott egészségi állapotú tanulók (egyének) teljesítőképességének és egészségi állapotának minél nagyobb százalékban történő helyreállítása; másrészt a nevelési folyamat eredményeként a rendszeres testedzés megszerettetése, az egészséges életmódra fogékony pozitív szemlélet kialakítása és a tanulók, felnőttek felkészítése arra, hogy életük során képesek legyenek elváltozásuknak, betegségüknek megfelelő testedzési formát megválasztani és végezni.

A gyógytorna Csermely ${ }^{9}$ szerint speciális mozgásterápia, amely a megbetegedett szerv vagy testrész funkciójának helyreállítására irányuló gyakorlatokat tartalmaz, mindig figyelembe véve az egész testet. A gyógytorna célja a mozgás és egyéb funkciók (vérkeringés, légzés, idegmúködés) helyreállítása, javítása.

A két rehabilitációs tevékenység számos jól meghatározható ponton különbözik egymástól [1. táblázat]. Itt szeretnénk kiemelni a legjelentősebb különbséget: a nevelést. A gyógytestnevelő tanár munkájának nagy részét teszi ki az egyének nevelés általi személyiségformálása. A gyógytestnevelés csak akkor lehet sikeres, ha fiziológiás változások mellett az egyénben az egészséges életmód iránti igény is kialakul. A tudatos életvezetésnek része a betegséghez, elváltozáshoz igazított testedzési formák végzése és a helyes táplálkozás, életvitel kialakítása. A gyógytestnevelésen részt vevőknél csak tudatosan felépített nevelési folyamat eredményeként tudjuk elérni az előzőekben leírtakat, amelynek kidolgozására és megvalósítására a pedagógiailag és szakmailag jól felkészült gyógytestnevelő a legmegfelelőbb személy. Az összehasonlítás során jól látható, hogy a gyógytestnevelés és a gyógytorna nem egymás ellen ható, hanem a rehabilitációs folyamatban egymásra épülő tevékenységek, amelyeknek összehangoltan kell múködniük.

Az előzőekből következik, hogy a gyógytestnevelés a rehabilitációs folyamat meghatározó eleme, amely nélkül nem valósulhat meg az egyén egészségének és munkavégző képességének lehető legnagyobb mértékű helyreállítása. E tény szükségessé teszi a gyógytestnevelés szoros kapcsolatát az egészségtudományokkal (anatómia, élettan, gyógytorna stb.), de az egészségi állapot és a teljesítőképesség sikeres helyreállításához és fenntartásához állandó kapcsolatot kell kialakítani a pedagógiával is.

1. táblázat: A gyógytestnevelés és a gyógytorna összehasonlítása²

\begin{tabular}{|c|c|}
\hline Gyógytestnevelés & Gyógytorna \\
\hline \multicolumn{2}{|c|}{ Azonosság } \\
\hline Egészség helyreállítása, megőrzése & Egészség helyreállítása, megőrzése \\
\hline Másodlagos prevenció & Másodlagos prevenció \\
\hline \multicolumn{2}{|c|}{ Különbség } \\
\hline Cél a teljesítőképesség helyreállítása & Cél a funkció helyreállítása \\
\hline Oktatási feladat & Egészségügyi feladat \\
\hline 5-16 fös csoportokban dolgoznak & 1-5 fős csoportokban dolgoznak \\
\hline Enyhébb elváltozások korrekciója & Súlyosabb elváltozások korrekciója \\
\hline Általános és célirányos izomfejlesztés & Célirányos izomfejlesztés \\
\hline Nevel, személyiséget formál & Csak a gyógyításra koncentrál \\
\hline Az egész személyt nézi, fejleszti & A betegség oldaláról közelít \\
\hline
\end{tabular}


A gyógytestnevelés az elsődleges rehabilitáció (gyógytorna) és az egészség helyreállása, fenntartása között mintegy katalizátor jelenik meg. A gyógytorna korrekciós gyakorlatait, a betegség gyógyítására koncentráló szemléletét egészíti ki a sport és a testnevelés testgyakorlataival, a pedagógia bevonásával pedig az ember teljességének szemléletével. E tényezők megjelenése felgyorsítja a rehabilitációs folyamatot, míg hiánya nagymértékben lelassítja, vagy több esetben visszafordítja az egészségi állapot javulását. A gyógytestnevelés ugyanakkor felkészít a testgyakorlatok és a személyiségformálás révén a rehabilitáció harmadik, végső szakaszára, az egészség fenntartására, fejlesztésére, amelynek megvalósítási formái a rekreációs célú testedzések, a sportolás (mozgásos rekreáció). A gyógytestnevelés nem csak a korrekcióra koncentrál, és így több, mint korrekciós gyakorlatok összessége. A gyógytestnevelés komplex terápiás folyamat, amely a testgyakorlatok révén nevel és személyiséget formál.

A fent leírtakból következően a gyógytestnevelés területeit két szempont alapján lehet csoportosítani:

- Betegségtípusok szerint:

- A tartó-és mozgatórendszer gyógytestnevelése,

- A belgyógyászati betegségek gyógytestnevelése,

- A fogyatékkal élők gyógytestnevelése,

- A mentális betegségben szenvedók gyógytestnevelése.

- Célcsoportok szerint:

- A 18 év alatti korosztály gyógytestnevelése (adaptált testnevelése),

- A felnőtt és idős korosztály gyógytestnevelése (adaptált sport vagy adaptált testedzés),

- A sportolók szekunder rehabilitációja (sportrehabilitáció).

\section{A GYÓGYTESTNEVELÉS ÉS A GYÓGYTESTNE- VELŐ TANÁRI MUNKA MEGÚJULÁSÁNAK TERÜLETEI}

Szakmai, tartalmi megújulás

A magyar lakosság aggasztó egészségi állapota szükségessé teszi a népegészségügy területén a rend- szerszintű megoldási javaslatok kidolgozását. A kidolgozás során elsődlegesen figyelembe kell venni a gyermek- és ifjúsági korosztályt, de nem lehet figyelmen kívül hagyni a felnőtt, munkaképes és a nyugdíjas lakosságot sem. Az eredményes munka érdekében össze kell hangolni a prevenció (szürések, rekreációs tevékenységek támogatása stb.), a primer rehabilitáció (gyógytorna), a szekunder rehabilitáció (gyógytestnevelés) és az egészségfejlesztés irányítását, amelyben a gyógytestnevelő tanárnak meghatározó szerepet kell kapnia. Egyértelműen (nem élesen) el kell különíteni a prevenció és a rehabilitáció különböző szintjeinek céljait, a szinteken végzendő feladatokat, tevékenységeket úgy, hogy az egymást követő szintek között bizonyos mértékú átfedések lehetőségét fenntartsuk. Jelenleg a gyógytestnevelés az óvodás és iskolás korosztály egészségének a helyreállításában fejti ki szervezett tevékenységét, az állami szerepvállalásnak köszönhetően. A felnőtt, idős korosztály, illetve a sportolók önfinanszírozással tudják megoldani a szekunder rehabilitációt, ami jelenleg a lehetőség minimális kihasználását eredményezi. Az állami finanszírozás kiterjesztése mellett szükséges a gyógytestnevelés tartalmi megújitása is, amelynek első lépése a szemléletváltás.

\section{Szemléletváltás}

Jelenleg a gyógytestnevelés területén dolgozó pedagógusok azon munkálkodnak, hogy az egészségi állapotot és a teljesítőképességet minél rövidebb idő alatt helyreállítsák, és többségük a gyógytorna szemléletéhez közelítve, kiemelten alkalmazza a korrekciós gyakorlatokat, ezzel csökkentve a gyógytestnevelés hosszan tartó hatásait. A szakemberek másik csoportja a különböző sportágak adaptációját felhasználva végzi a rehabilitációs tevékenységet. A jelenlegi gyógytestnevelési munkában csak részben valósul meg az egyik fontos távlati cél: a tanulókat képessé tenni arra, hogy a felnőtt korukban végezhető, az elváltozásuk, betegségük javítását, tünetmentességét és egészségük fejlesztését szolgáló mozgásformákat, edzésformákat ki tudják választani. A szemléletváltás eredményeként a gyógytestnevelés minden tevékenységét az előzőekben említett célnak kell alárendelni. A nevelésnek, a felkészítésnek hangsúlyosabban kell megjelenni a gyógytestnevelői munkában, ami nem jelenti a jelenlegi tevékenységek gyökeres megvál- 
toztatását, a korrekciós gyakorlatok számüzését. $A z$ új szemlélet tudatosabb tervezést, munkát igényel a gyógytestnevelő tanártól. Felül kell vizsgálnia, hogy az eddig felhasznált testgyakorlatok, oktatási és nevelési módszerek, eljárások megfelelnek-e a távlati céloknak, és ezek szerint kell megújítani a tantervet, a tanmeneteket. Az új tantervekben megfelelő egyensúlyban kell megjelenniük a korrekciós gyakorlatoknak, a sportjátékoknak, a különböző sportági ismereteknek és nem utolsó sorban a testnevelési játékoknak, de meg kell jelenniük azoknak a szabadidős tevékenységeknek is, amelyek végzése elősegíti az egészség fenntartását és fejlesztését. Az előzőekben felsoroltakat kiválóan szolgálja a mindennapos testnevelés bevezetése. A heti öt gyógytestnevelés óra lehetőséget biztosít minden terület megfelelő idejű fejlesztésére.

A szakmai megújulás tárgyalásakor nem kerülhetjük meg a nevelői felfogás adaptálását a mai kor fiataljához, emberéhez. Napjaink gyógytestnevelő tanára a tekintélyelvű pedagógiával nem végezhet eredményes munkát. Empatikus, megértő tanárként meg kell nyernie a feladatoknak a tanulókat, és facilitátorként végeznie a munkáját. Kutatásaink is bizonyították, hogy ennek a szerepnek a gyógytestnevelő tanárok legnagyobb része megfelel. ${ }^{3,10}$ Ezen a területen elsősorban a megerősítés szükséges a gyógytestnevelő tanárok számára, hogy korszerü és megfelelő felfogással közelítenek a tanulókhoz. Új elem lehet a szülőkkel való kommunikációs technikák elsajátítása, az ő támogatásuk nélkül a gyógytestnevelő tanár kiszolgáltatottá válik a rehabilitációs folyamatban.

\section{Sportrehabilitáció}

Az utánpótlássport fejlesztése, a sportági akadémiák számának növekedése, a versenysport utánpótlásában megvalósuló teljesítménycentrikus felfogás elterjedése, valamint a nem minden vonatkozásban körültekintő felkészítés következtében az utánpótláskorú versenyzők körében megnőtt a súlyos sportsérülések száma, amely nem megfelelő kezelés esetén a sportoló karrierjébe is kerülhet. Jelenleg az utánpótlás-egyesületek esetében nem fordítanak megfelelő figyelmet a fiatal sportolók szakszerű rehabilitációjára. Minél fiatalabb egy versenyző, annál kevésbé törődnek az egészség és a teljesítőképesség nagyarányú, gyors és szakszerú helyreállításával. Sok esetben az erőnléti edző, személyi edző vállalja fel a rehabilitációt annak ellenére, hogy nincs erre a területre szóló szakirányú végzettsége. A tanulmány elején már említett rehabilitációs folyamat fokozatainak (gyógytorna, gyógytestnevelés, rekreáció) a versenysportban is meg kell jelenniük. A gyógytornász szakma, mint az elsődleges rehabilitáció megvalósítója, felismerte a versenysport igényét a szakszerű rehabilitáció iránt, és mester-, illetve szakirányú képzésekben részesíti a szakembereket. A szekunder rehabilitációt végző gyógytestnevelő tanároknak is be kell kapcsolódniuk a sportrehabilitáció folyamatába, hiszen pedagógiai, edzéselméleti, sportágismereti és mozgásterápiás felkészültségük, egészségcentirkus szemléletük alkalmassá teszi őket a sportrehabilitáció második szakaszába való bekapcsolódásra. A képző intézmények feladata, hogy a gyógytestnevelő tanárok képzésébe, illetve továbbképzésébe beépítse a sportrehabilitációs szakemberek képzését, ezzel megteremtve a szakma számára a lehetőséget a sportrehabilitáció területén való tevékenységre. A sportegészségügy feladata pedig, hogy a sportorvosi hálózatra építve ezen a területen is egy sportrehabilitációs munkacsoportot hozzon létre, amelyben a sportorvos mellett gyógytornász, gyógytestnevelő és teljesítménydiagnosztikával foglalkozó szakember végzi a preventív, rehabilitációs munkát kooperatív együttműködés keretében, a rehabilitációs folyamatot egymás munkájára építve.

\section{A felnőtt és idős lakosság rehabilitációja, egészség- fejlesztése}

A nyugdíjas korú lakosság száma, és így arányszáma is világszerte növekvő tendenciát mutat. ${ }^{11} \mathrm{~A} X X \mathrm{XI}$. századi nyugdíjas már nem csak 5-10 évre tervezhet, hanem jóval hosszabb időszakra. A meghoszszabbodott élettartam sok esetben fizikailag inaktív életmóddal párosul, ami számos betegség megjelenésével jár együtt, köztük a vezető helyen szereplő szív- és érrendszeri, valamint a mozgató szervrendszeri betegségekkel. A rendszeres fizikai és szellemi aktivitás meghatározó tényezője a betegségek megelőzésének, és nagymértékben lassítja a szellemi és a fizikai leépülés folyamatát. A 60 év feletti korosztály egy része (még nem elegen) már felismerte a rendszeres, testmozgás, testedzés jelentőségét a betegségek és negatív mentális állapotok megelőzésében, az öregedési folyamatok lassításában és a fizikai cselekvőképesség fenntartásában. ${ }^{12,13}$ 
A sérülésekből, balesetekből, illetve a helytelen életmódból fakadó betegségek szekunder rehabilitációja jelenleg nem megoldott a felnőtt, illetve az idős korosztály körében. A felgyorsult, munkacentrikus világunkban jelentősége van annak, hogy az egyén milyen gyorsan és milyen mértékben tudja visszanyerni munkavégző-képességét. Az elsődleges rehabilitációval, a gyógytornával és a különböző fizioterápiás kezelésekkel elért eredmények legtöbb esetben nem biztosítják a teljes munkavégző-képesség, illetve teljesítőképesség visszaszerzését. Az elsődleges rehabilitációnak ez nem is célja és nem is feladata. A szekunder rehabilitációnak, így a gyógytestnevelésnek (adaptív testedzésnek) a célja és feladata teljesítőképesség minél nagyobb arányú helyreállítása. A gyógytestnevelő a mentális, a fizikai és az egészségi állapothoz igazított testedzéssel, a terhelés egyéni sajátosságok (életkor, sportelőélet, betegségtípus stb.) figyelembevételével képes a rehabilitációs folyamat nagymértékű rövidítését elérni. A gyógytestnevelők egészséges mértékben teljesítménycentrikus, egészségközpontú, a személyeket középpontba helyező, holisztikus szemlélete alkalmassá teszi őket a felnőtt és az idős korosztály szekunder rehabilitációjában, prevenciójában való sikeres munkára. Az alkalomszerǔen, illetve rendszeresen szervezett különböző egyéni és csoportos programok segítségével a gyógytestnevelő sokat tehet a felnőtt- és idős korosztály egészségfenntartása és -fejlesztése, a munkavégző-képesség és a cselekvőképesség helyreállítása és fenntartása érdekében.

\section{Szerkezeti megújulás}

\section{"Utazó" és iskolai gyógytestnevelők}

A 2011. évi CXC törvény a nemzeti köznevelésről, ${ }^{14}$ illetve az azt követő 15/2013. (II. 26.) EMMI rendelet megváltoztatta a gyógytestnevelés szerkezeti megjelenését. ${ }^{15} \mathrm{Az}$ addig rugalmasan, jó hatásfokkal múködő rendszert, amelyben a tanuló elsősorban saját iskolájában, az iskolájában dolgozó gyógytestnevelő tanár munkájának eredményeként juthatott ellátáshoz, és csak kisebb mértékben látta el a feladatot a pedagógiai szakszolgálat (a gyógytestnevelő tanár hiánya, illetve a fenntartói döntés következtében), felváltotta az iskolától sok tekintetben független, kisebb hatásfokkal múködő rendszer. A régi, vegyes rendszer révén jól múködött az ellátás, mert a legjobb személyi és tárgyi feltételekkel rendelkező szervezeti formában valósult meg a rehabilitáció. Ennek legfőbb nyertese a gyermek volt. Az új szerkezeti rendszerben sok gyógytestnevelő tanárnak választania kellett a testnevelés és a gyógytestnevelés tanítása között, ${ }^{16}$ és többen a testnevelés tanítását választották, így sok jól képzett gyógytestnevelő tanár került ki a rendszerból. Az utazó gyógytestnevelő (a pedagógiai szakszolgálatok nagyrészt így oldják meg az ellátást) tanár csak az órán találkozik a diákkal, és ez az idő kevés a célok teljes mértékű megvalósítására, a tanulók megismerésére.

Fontos, hogy a gyógytestnevelő tanár elsősorban a saját iskolájában lássa el a feladatát, ahol a tanórán kívül is rendszeresen találkozhat a tanulóival, ami hozzásegíti a felmerülő problémák gyorsabb megoldásához, és így összességében hatékonyabban tudja végezni a munkáját. Azokban az iskolában, ahol nincsenek meg a személyi feltételek, ott a pedagógiai szakszolgálat lássa el a feladatot. A vegyes rendszer a leghatékonyabb, mivel az adott iskolában a lehetőségek szerint a legjobb ellátási forma valósulhat meg. A jövő feladata lesz, hogy különböző fórumokon a döntéshozókat meggyőzzük a vegyes forma hatékonyságáról, és visszavezetésének szükségességéről. A készülő új Nemzeti Alaptanterv egyike lehet azon fórumoknak, ahol ezt a munkát elvégezhetik a szakma érdekképviseletét ellátó szervezetek.

\section{Egészségügyi munkacsoportok felállítása az iskolákban}

A szerkezeti megújulás másik lényeges területe a szúrés és az egészségfejlesztés irányítása. Jelenleg a szűrésért felelős egészségügyi rendszer, benne az iskolaorvosi rendszer, illetve az ellátást végző oktatási rendszer, benne a gyógytestnevelő tanár összehangolt munkája nem valósul meg. Kivételekkel találkozhatunk, de ezek nem a rendszer jó múködéséből fakadnak, hanem a részt vevő személyek elhivatottságából. Szükséges felállítani iskolánként egy egészségügyi munkacsoportot, amelyet az iskolaorvos, a gyógytestnevelő tanár, a testnevelő tanár (amennyiben a gyógytestnevelő tanár nem az iskolában dolgozó testnevelő tanár) a védőnő és lehetőség szerint az iskolapszichológus (mentális egészség) alkot.

A feladatot függetlenített iskolaorvos, védőnő, pszichológus és az iskola tantestületébe tartozó gyógytestnevelő tanár látná el. A munkacsoport legfontosabb feladata a tanulók megfelelő kategóriába sorolása. A kategóriába sorolást jelenleg az 
iskolaorvos végzi a szakorvos által megadott diagnózis alapján, és sok esetben nem veszi figyelembe a tanulók mentális állapotát, képességeit, a testedzéssel kapcsolatos attitűdjét. A gyógytestnevelő tanár (testnevelő tanár) bevonása a döntési folyamatba, nagyban elősegíti a tanuló fejlődése szempontjából a legjobb besorolási kategóriába sorolást. Sok esetben előfordul, hogy az orvosi diagnózis alapján a tanuló könnyített testnevelésen vehetne részt, de számára a gyógytestnevelés hatékonyabb, adekvátabb forma lenne az egészségi állapotának és a teljesítőképességének a helyreállítása szempontjából. Az egészségügyi munkacsoport több szempont figyelembe vételével hozza meg a döntését, amely a tanuló motoros fejődésén túl a személyiségfejlődését is elősegíti. Ez biztosítja a hosszú távú célok elérését. A munkacsoport másik nagy feladata az iskolai egészségfejlesztés tervezése, szervezése és irányítása, amelyben a gyógytestnevelő-egészségfejlesztő tanárnak meghatározó szerepet kell szánni.

\section{ÖSSZEGZÉS}

A gyógytestnevelés több mint 100 éves múltra tekint vissza, és Európában csak hazánkban valósul meg ebben a szervezett formában. A múlt és a szakmában dolgozók elhivatottsága a gyógytestnevelésért tenni akaró embereket arra kötelezi, hogy a szakma megújitásával, időszakonként új célok és feladatok kijelölésével elősegítsék a gyógytestnevelés folyamatos fejlődését, szakmai elismertségének növelését. A gyógytestnevelés megújulása ma nagyon időszerū. A társadalmi változások szükségszerǔvé tették új célok és feladatok kijelölését, amelyek egyértelműen meghatározzák a gyógytestnevelés helyét és szerepét a rehabilitációs folyamatban. Ebben a gyógytestnevelés meghatározó szerepet tölt be, és a sikerhez fontos a rehabilitáció különböző szintjein dolgozók együttmúködése. Kiemelt feladatnak tartjuk, hogy a meglévő értékek megtartása mellett a gyógytestnevelés szemléletében, tartalmában megújuljon, alkalmazkodva napjaink kihívásaihoz.

\section{HIVATKOZÁSOK}

\footnotetext{
${ }^{1}$ Zaletnyik Z, Repiszky T (szerk.). A gyógyító mozgás művésze, Madzsar Alice emlékének. Budapest, Semmelweis Kiadó, 2012.

2 Simon I. A gyógytestnevelés elmélete és módszertana. Szombathely, Nyugat-magyarországi Egyetem SEK, 2015.

${ }^{3}$ Simon IÁ, Kajtár G. A gyógytestnevelés órán alkalmazott sajátos gyógytestnevelő tanári módszerek. Magyar Sporttudományi Szemle. 2016;17(66):58.

${ }^{4}$ Kopkáné Plachi J. A rendszeres fizikai aktivitás hatása az idős kori függetlenség megőrzésére 60 év fölötti nők esetében: randomizált kontrollált kísérlet. Doktori dolgozat, Testnevelési Egyetem, 2014.

${ }^{5}$ KSH (2016) http://www.ksh.hu/docs/hun/xstadat/xstadat eves/i wdsd008.html Elérve: 2017. 03. 19.

${ }^{6}$ Punyi AC. Kvoproszu o pszihologicseszkih osznovah lecsebnoj fizicseszkoj kulture. Fizkultura i Szport. 1959;27:25.

${ }^{7}$ Nemessúri M. Gyógytestnevelés. Budapest , Tankönyvkiadó, 1965., p. 25

${ }^{8}$ Gárdos M, Mónus A. Gyógytestnevelés. Budapest, Testnevelési Főiskola, 1991.

${ }^{9}$ Csermely M. Fizioterápia. Budapest, Medicina Kiadó, 2009.

10 Simon IÁ, Kajtár G. A gyógytestnevelő tanár nevelői, szakmai attitűdje. Magyar Sporttudományi Szemle. 2015;62(2):60.

${ }^{11}$ Molnár E. Az időskorú népesség jellemzői és életkörülményei, Budapest, KSH 2004.

12 Herpainé Lakó J, Olvasztóné Balogh Zs. Nagyszülők és unokák testedzésének aktuális kérdései az egészségfejlesztés tükrében. Egészségfejlesztés. 2007;48(1-2):14-6.

${ }^{13}$ Olvasztóné Balogh Zs, Herpainé Lakó J, Bognár J, et al. Idős emberek életkörülményeinek és egészségmagatartásának vizsgálata. Egészségfejlesztés. 2011;52(5-6):24-30.

14 2011. évi CXC. törvény a nemzeti köznevelésről

15 15/2013. (II. 26.) EMMI rendelet a pedagógiai szakszolgálati intézmények működéséről

${ }^{16}$ Vezér K, Pánger A, Farkas A, Bosnyák E, Simon IÁ. A gyógytestnevelő tanár helyzete és jövőképe napjaink köznevelési rendszerében. In: 47. Mozgásbiológiai Konferencia program és előadás kivonatok. 2017. p. 32-3.
} 